\title{
Multiple Shocks and Risk Management Strategies among Rural Households in Zambia's Mazabuka District
}

\author{
Thomson Kalinda ${ }^{1}$ \\ ${ }^{1}$ Department of Agricultural Economics \& Extension, University of Zambia, Lusaka, Zambia \\ Correspondence: Thomson Kalinda, Department of Agricultural Economics and Extension, University of Zambia, \\ Lusaka, Zambia. Tel: 260-9-6645-4366. E-mail: thomsonkalinda@gmail.com
}

Received: July 18, 2014

doi:10.5539/jsd.v7n5p52

\author{
Accepted: August 18, 2014 Online Published: September 14, 2014 \\ URL: http://dx.doi.org/10.5539/jsd.v7n5p52
}

\begin{abstract}
The objective of this study was to document the kinds of shocks or set-backs and events that commonly cause households to become poorer or destitute and the kinds of risk management strategies they utilize in order to prevent, mitigate or cope with the shocks. The study was conducted in Magobbo area which is located in Mazabuka District in Zambia's Southern Province using qualitative research methods and techniques. The results show that the majority Magobbo households face multiple covariant and idiosyncratic shocks which have led to downward economic mobility or increased poverty. Some of the shocks include market access challenges caused by market liberalization policies; increased morbidity and mortality due to the HIV and AIDS pandemic and other diseases; adverse consequences of climate change and deterioration of the natural resources; adverse consequences of family breakdown caused by spousal abandonment, divorce and widowhood. The study results also show that the households practice several coping mechanisms to address shocks and set-backs that affect them. These coping mechanisms include a range of prevention, mitigation and coping strategies.
\end{abstract}

Keywords: poverty, economic mobility, covariant and idiosyncratic shocks, risk management strategies, Zambia

\section{Introduction}

In recent years, Zambia has experienced high rates of economic growth. The Zambian economy has been performing relatively well, with real Gross Domestic Product (GDP) growth averaging over $6.0 \%$ in the period 2001 to 2011(Central Statistical Office, 2012a). Despite these high rates of economic growth in Zambia, disparities between the rich and the poor continue to prevail, especially in rural areas. Currently, poverty is widespread in Zambia, with about $61 \%$ of the people in the country living below the poverty line and above half of them are considered to be in extreme poverty. Moreover, despite significant improvements in urban poverty reduction, poverty remains an acute problem for the rural people who make up the majority of the country's population with rural poverty rates being stuck at over 77 per cent for more than a decade (Central Statistical Office, 2012a).

Furthermore, while chronic poverty is a serious concern in Zambia and other developing countries, poverty is not always a fixed or static phenomenon. It is dynamic, with people or households managing to escape poverty under favorable conditions or becoming destitute when conditions deteriorate. There are many factors and forces that cause people to become either destitute or better off. However, the poor households in rural areas are particularly more vulnerable to becoming destitute. The poor rural households face higher risks of downward mobility caused by a variety of shocks or set-backs. Understanding these shocks and set-backs from the perspective of rural households is important in order to establish and implement policies to minimize these negative factors. This paper therefore attempts to understand the poverty dynamics in Zambian rural households. The objective of this study was to document the kinds of shocks or set-backs that commonly cause households to become poorer or destitute and the kinds of risk management strategies they employ in order to prevent, mitigate or cope with the shocks in Magobbo area which is located in Mazabuka District, Zambia. The rest of this paper is structured as follows. The conceptual framework is presented in section 2, followed by the methodology in section 3 . The results and discussion, and conclusions are then presented in sections 4 and 5, respectively.

\section{Conceptual Framework}

The paper utilizes the livelihood framework and the Social Risk Management (SRM) framework to try to 
understand and document the kinds of shocks or set-backs that commonly cause households in rural areas to become poorer or destitute and the kinds of risk management strategies they employ in order to prevent, mitigate or cope with the shocks. Livelihood frameworks are frequently used by researchers to document and analyze the processes by which individuals and households utilize their resources and opportunities to make a living in particular socio-economic and biophysical contexts (Scoones, 1998; Carney, 1998; Ellis, 2000; Shanmugaratnam, 2008; Haan \& Zoomers, 2005). A livelihood is defined as comprising "the assets (natural, physical, human, financial and social capital), the activities, and the access to these (mediated by institutions and social relations) that together determine the living gained by the individual or household" (Ellis, 2000: 10). Put simply, a livelihood is a living gained using endowments (assets), activities and opportunities. Individuals and households, using their endowments, engage in different activities within the bounds of the opportunity structures presented by a particular set of mediating factors (environmental, institutional, infrastructural, technological and socioeconomic) (Chambers, 2006). "The Vulnerability Context frames the external environment in which people exist. People's livelihoods and the wider availability of assets are fundamentally affected by critical trends as well as by shocks and seasonality - over which they have limited or no control" (DFID, 2000: 3).

Rural livelihoods are often exposed to various risks and shocks. Human and livestock diseases, climate variability, pests, flooding, unfavourable market trends, institutional deficiencies, and so on, can present risks and inhibit livelihood endeavours. In the literature, a distinction is made between individual household-specific (idiosyncratic) shocks, for instance, illness and death of a household member, and covariate shocks which have an impact on a larger group of population in the same area at the same time such as weather adversity and market fluctuation (Dercon, 2004). A number of studies have shown that risks and shocks can perpetuate poverty and aggravate vulnerability to livelihood failure by inducing asset sales, and through lost income (Dercon, 2004; Dercon, 2005a; Dercon, 2005b). In particular, climate variability is known to cause severe impacts on livelihoods which are sensitive to climate change, such as rain-fed agriculture (Adger et al., 2003; Vogel, 2005; Yamin et al., 2005). Farmers are known to practise different adaptive strategies to minimize the effect of climate variability and to enhance and maintain the quality of their land, but such efforts are dependent on access to resources (Mortimore \& Adams, 2001; Adger \& Vincent, 2005).

Orthodox analyses of the coping mechanisms of rural households tend to focus on actions that are taken to address the effects of a shock after it has occurred. However, there is a growing awareness that rural households take actions that prepare them effectively for unexpected shocks, or, in some cases, prevent them from occurring. This awareness was formalized in the Social Risk Management (SRM) framework, which has become a valuable tool for analyzing risks and coping mechanisms. The SRM framework categorizes risk management strategies into three classes, namely, Risk Reduction Strategies, Risk Mitigation Strategies and Risk Coping Strategies (Holzmann \& Jörgensen, 2000; Holzmann et al., 2003; Farrington, 2005). The Risk Prevention strategies refer to actions or approaches aimed at reducing the risk of occurrence of adverse shocks. Examples of these include the cultivation of drought resistant crops or the practice of soil and water conservation measures to reduce the probability of crop failure in agriculture. The Risk Mitigation strategies are actions or approaches aimed at reducing the potential impact of a shock or stress. An example of this in agriculture is irrigation of a crop when a dry spell or drought occurs. Risk Coping strategies are actions or approaches aimed at relieving the impact of a shock once it has occurred (Farrington et al., 2004; Farrington, 2005).

\section{Methodology}

\subsection{Study Area}

The study was conducted in Magobbo area which is located in Mazabuka district of the Southern Province of Zambia. Mazabuka district is located about 125 kilometers from Lusaka, the capital city of Zambia. Mazabuka district is located directly south of and adjacent to the Kafue Flats which is the flood plain portion of the Kafue River. The population of Mazabuka is estimated to be about 230,972 people with about seventy five percent (75\%) of the population living in the rural area (Central Statistical Office, 2012b). The maps in Appendix 1 and 2 show the location of the Southern Province and Mazabuka district in Zambia, and the location of the study area, Magobbo, in Mazabuka district, respectively.

Magobbo area covers an area of about 1,800 hectares. The land is a mixture of customary and private land. Smallholder farmers, retired employees and local indigenous people, cultivate various crops for livelihoods on fields located near their homesteads. The remainder of the area is used by the community for other developments and livestock grazing. Some smallholder farmers are engaged in a variety of informal agricultural activities that tend to be short-term, seasonal and frequently unsuccessful resulting in food insecurity and general rural poverty (Whydah Consulting, 2011). 
Farming is the dominant economic activity in Magobbo with maize constituting the single largest cultivated crop Other important crops in the area are groundnuts, cowpeas, sugar cane, soybeans, sweet potatoes, cotton, sorghum, and millet. Households also keep livestock, like cattle, goats, pigs and poultry. The Magobbo area is located about $12.5 \mathrm{~km}$ from the Zambia Sugar Plc. mill at Nakambala and since October 2009, about 28 farmers in the area have been producing sugarcane under an out grower scheme arrangement managed by the Sugar Company. Under this outgrower scheme, the Zambia Sugar Plc. provides training and infrastructure like the irrigation furrows for the production of the sugar cane crop by the contract farmers.

\subsection{Approach and Process}

The Participatory Rural Appraisal (PRA) approach was utilized to collect information in six selected communities within Magobbo. The author and two research facilitators with experience in organizing focus group discussions (FGD) conducted the interviews. The research facilitators were debriefed by the author on the purpose of the study to ensure that appropriate information was collected from the respondents.

\subsubsection{Process of Data Collection}

After getting informed consent from the local leadership, community members were invited to open meetings in the village. The author and the facilitators then introduced and explained the objective of the research activity to the residents. After this introduction, groups of individuals residing in defined village sections were asked to get together for FGD. The FGD were held with six to twelve community members at a time. These were usually the household heads along with their spouses. The groups were first led in a facilitated discussion on aspects of poverty in the village. To begin with, the participants were asked by the facilitator to explain their understanding of poverty or wealth and its characteristics. The rationale behind this probing was to set the context for the subsequent topics that were going to be discussed.

After this probing to describe the wealth or poverty characteristics of households in their community, participants in the FGD were asked to mention and explain changes or trends that have affected the livelihoods or economic standing of Magobbo village overall during the past ten to twenty years. The rationale was to elicit the views of the respondents on the macro and meso level changes that have affected the rural households in Magobbo. They were asked to indicate if any households in Magobbo have changed their wealth or poverty status, that is, if they have experienced economic mobility, either upwards or downwards as a result of these changes in the past ten to twenty years.

Lastly, the respondents in the FDG were asked to identify important shocks or set-backs in their households and community and to explain or comment on what has been the impact of these shocks and set-backs on the households in terms of their wealth or poverty status, livelihood strategies and so on. The participants were further probed to identify and describe what the residents of Magobbo usually do to prevent, mitigate or cope with the effects of these shocks. The discussions were full with detail and the proceedings of the resulting discussions were recorded or captured by the facilitator for analysis and synthesis later on.

Some key informants like government agricultural extension workers and health personnel in the area were also interviewed to further validate some of the issues that were raised by the respondents in the FGD. This was particularly with regard to issues concerning the quality of service provision from public institutions as well as other pertinent issues in Magobbo area.

\subsubsection{Data Analysis}

The largely qualitative data which was collected during the FGD and key informant interviews was analyzed by the author with the assistance of the two research facilitators. While the author and the research facilitators were mainly responsible for the data analysis and interpretation, the Magobbo residents who participated in the FDG also analyzed and interpreted the information that they provided during the discussion through further probing.

A number of methods were used to analyze the data that were collected. These included content analysis, causal analysis, and comparative analysis. Exposing the data to such meticulous analyses helped to corroborate their objectivity and credibility to ensure that they provided a sound understanding of the characteristics of the poor and wealthy households, the various shocks affecting the Magobbo community as well as the risk management strategies being employed.

\section{Results and Discussion}

\subsection{Characteristics of the Poor and Wealthy Households}

The FGD provided information on the characteristics by which poverty is comprehended by the people in Magobbo. In the understanding of the community members, poverty is viewed as a condition which can be 
manifestly observed by the degree or level of ownership or access to material resources. It is a state, with clear variations or degrees from "very poor" to "moderately poor" to "better-off" to "well-off or wealthy". In similar vein, the following discussion highlights the main characteristics of these poverty or wealth classes based on descriptions by the respondents and the author's observations in the community.

The "very poor" people in Magobbo can generally be identified as people who fail to meet their basic requirements such as food. This arises from their inability to produce enough food and income due to lack of resources like fertilizer and livestock. The problem of failure to have enough food is so critical that some poor households only have one meal in a day whilst others even beg for food from those who are better off. The general poor nutrition of these poor households makes some of them to be chronically ill. Some of the poor also are involved in casual labour or piece-work within and outside their respective villages as a strategy for obtaining income and food (in most cases, they are paid in-kind with food items like sweet potatoes, groundnuts, pork, goat meat and cowpeas). They cultivate small areas and have poor yields because they spend most of their time and effort working in other people's fields. The very poor in Magobbo also depend on the local area forest to make charcoal or gather firewood and wild foods such as fruits, nuts and mushrooms for sale within village markets. The old and/or female-headed households who have large families (including orphans) to look after are among the very poor in Magobbo. The female-headed households are composed of widows or women who have been deserted by their husbands. Some of the poor are disabled and are lowly educated. They also fail to send their children to secondary schools where fees and other charges are levied. In addition, they are poorly dressed and do not possess adequate beddings. They own poorly constructed mud huts with grass thatched roofs.

The "moderately poor", or less poor, own houses that are usually thatched with grass but, unlike the "very poor" or poorest, may have a cement floor. The "moderately poor" also own a few assets such as livestock (commonly small livestock such as goats and chickens); cooking utensils; and farm implements like hoes. They typically do not own implements like ox-ploughs and do not own oxen. The lack of oxen and ploughs usually limits the amount of land these households cultivate. However, since they are able to farm using the basic hoe, they produce at subsistence level and are considered to be basically food secure even though they experience occasional food shortages during the lean season. They normally maintain an acceptable level of consumption.

In contrast, the "better-off" and "well-off or wealthy" people have similar characteristics with minor differences in terms of asset ownership. The better-off or wealthy people differ from the poor in that they are resource rich. They own and live in houses constructed with burnt bricks and corrugated iron roofs. They own assets like bicycles, radios, TVs and livestock like cattle, goats, pigs and chickens. They are able to produce enough food and even hire other people, particularly, the poor to work for them in their fields. They own vegetable gardens in addition to the regular fields (sweet potatoes, millet, maize, beans, groundnuts, millet fields). In the vegetable gardens where they irrigate using furrows; they produce tomatoes, onions, cabbages and other leafy vegetables, which they sell locally and in Mazabuka.

The better-off or wealthy households are the ones who mostly cultivate large land areas and produce surpluses for sale. In Magobbo, some of these wealthy households are involved in production of sugar cane under an out grower scheme arrangement with the Zambia Sugar Company. After harvesting, the sugar cane is delivered to Zambia Sugar Plc. for processing. The Magobbo farmers are paid for the sugar supplied after the costs are met in accordance with the out grower contract. Some of the well-off or better-off households are involved in fish trading. They travel to Mazabuka to buy fish which they bring back to sell in the local community. These households are also relatively more skilled in income generation as compared to the poor. For instance, they possess skills such as carpentry, masonry or bicycle repairing which they use to raise more income. Some of them also receive remittances from their children in urban areas. This study's finding on the key characteristics of poverty or wealth among rural households are similar or consistent with findings elsewhere in Africa (Ashong \& Smith, 2001; Ellis \& Mdoe, 2003; Van Campenhout, 2006; Aryeetey et al., 2013).

\subsection{Trends or Changes in Poverty and Other Local Conditions}

Informants in the FGD were asked to identify changes or trends that have affected the livelihoods of Magobbo area or village as a whole during the past ten to twenty years. The probing and discussions was aimed at highlighting the medium to long term changes, trends and covariate shocks that affect the entire village or community in terms of losing or gaining income. From the outset, the respondents were of the opinion that few households have experienced upward economic mobility while the vast majority of households have generally experienced downward economic mobility in the past ten to twenty years. The following presents the factors or shocks that were identified as systemic causes of the changes in livelihoods and poverty levels in Magobbo: 


\subsubsection{Increased Poverty Due to Liberalization Policies}

Most of the residents in Magobbo believe that overall poverty levels have increased during the past 10-20 years and is still increasing. Liberalization measures, many of which have been in place for over three decades, were at least partially to blame. Government policy has been characterized by liberalization policies in which market forces have determined the prices of goods and services in the economy. Most forms of government control or subsidies have been abolished. These liberalization policies have been implemented under the auspices of various structural adjustment programmes. For instance, in the agricultural sector, the government has reduced or withdrawn input subsidies and liberalized output markets. Similarly, user fees have also been introduced in the provision of public services like education and health.

The liberalization policies have harmed the majority poor households in Magobbo in that they cannot access public services and farming inputs. Their limited incomes constrains them from affording the various user fees for education and health services as well as in purchasing agricultural inputs like hybrid seeds and fertilizer. This has left these poor households in a serious predicament in which they are failing to send their children to secondary schools as well as fail to get proper medical care when they are sick. They are also failing to produce enough food (maize) because of lack of sufficient hybrid seed and fertilizer.

The inability to pay for agricultural inputs was mentioned as the main cause for the increase in poverty in Magobbo. In particular, the cost of fertilizer has sharply increased in recent years. Under a government supported Farmer Input Support Programme (FISP) subsidized inputs including fertilizer are sold to a few farmers who are registered members of agricultural cooperatives. However, the allocation of fertilizer to the cooperatives is insufficient to meet the requirements for all the registered members. Furthermore, many of the poor farmers are simply unable to buy fertilizer on the open market due to the high cost of the input. This inability to purchase important inputs like fertilizer has led to poor crop productivity and hence increased poverty levels. These findings are consistent with other studies on poverty and vulnerability in Zambia and elsewhere which show that agricultural market liberalization policies have negatively affected poor farm households (Orr \& Mwale, 2001; World Bank, 2007).

\subsubsection{Climate Change and Deterioration of the Environment}

Changes in the climate and environment were identified as causes of increased poverty among the residents of Magobbo. Most of the community members rely on rain fed agriculture to produce maize, the staple crop, and several other crops. The informants were of the perception that the rainfall patterns have increasingly become erratic over recent decades. The informants observed that droughts and floods have become more common in the area. Some extended dry spells and droughts affected households in Magobbo and other parts of Mazabuka. They lost their food crops like maize leading to food shortages.

Some informants also observed that there has been an over-exploitation of natural resources, such as trees and other forest products, and fish in the local streams and rivers. For example, there has been increased deforestation due to charcoal burning. As a result, poor households that rely on these resources as a livelihood option or coping mechanism can no longer do so. This finding is consistent with earlier studies in Zambia and Uganda which showed that demographic pressures, poor agricultural practices, land shortages and poverty induced natural resource exploitation such as charcoal burning have been the leading causes of environmental degradation (Francis et al., 1997; The Republic of Uganda, 2002; Helgeson et al., 2013).

\subsubsection{Increased Morbidity and Mortality}

Generally, residents in Magobbo have the perception that there has been an increase in diseases afflicting community members which has led to increased morbidity and mortality. Increases in diseases such as HIV and AIDS, diarrheoa, tuberculosis, eye infections, epilepsy and malaria have partly been attributed to poor nutrition and inadequate access to health services due to the introduction of user fees and long distances covered to reach clinics or hospitals. The general poor health status of most community members has negatively affected the people in so many ways. In discussions with community members in Magobbo, it was noted that more people in villages die now as compared to what was the case in the past mainly due to the HIV and AIDS pandemic. Relatives (sons and daughters) from urban areas return to the village due to morbidity caused by HIV and AIDS. Care for the sick has been an expensive burden for most rural households. In similar vein, some households have also been burdened with the responsibility of looking after orphans. The increase in chronic illness and mortality experienced Zambia in the past three decades is a serious cause of increased poverty among households. This finding in Zambia is in line with other studies in countries such as Uganda, Tanzania and Malawi which have shown the impoverishing effects of the HIV and AIDS pandemic (Bird \& Shinyekwa, 2003; Kessy, 2005; Orr \& Mwale, 2001). 


\subsubsection{Increase in Single-Parent or Child-Headed Households}

The informants in the FGD observed that, compared with some two decades ago, there has been an increase in the number of single-parent or child-headed households in Magobbo. Most of these single-parent households are female-headed. The increase in female-headed households is attributed to a several factors. The main factor is that, initially, HIV and AIDS infection rates mainly rose more rapidly among males than among females. This led to higher mortality among men and a general shortage of men and an increase in widowhood in the community. The widows consequently are insecure to remarry because potential partners are aware of the risks of marrying "AIDS widows". Polygamy which is traditionally practiced among the Tonga ethnic group is also on the decline due to fear of HIV and AIDS, and for economic reasons. Levirate marriages or widow inheritance is another customary practice that is declining after strong awareness campaigns against the practice by the government, non-governmental organizations (NGOs) and traditional leaders.

Furthermore, in some cases, men who abuse alcohol have been known to abandon their spouses and families. The rise in single-parent, particularly, female-headed households has led to increased vulnerability. The abandoned female spouses remain alone to take care of the needs of their children, with perhaps little support from their extended family. If the women do not get much support from their extended family, the level of desperation leads some women to engage in prostitution or transactional sex to support their families. Involvement in prostitution further exposes the women to risks of HIV and AIDS infections and thus exacerbating the problem of child-headed households. This finding is consistent with findings in other studies in Malawi and Zambia which show the vulnerability of rural women and their involvement in transactional sex as a livelihood strategy in the face of increased poverty (Bryceson \& Fonseca, 2006; World Bank, 2007; Kalinda \& Tembo, 2010; Malesu, 2013).

\subsubsection{Influx of Migrants and Changes in Access to Land}

During discussions on any changes or trends taking place in Magobbo, some of the informants identified the migration that is taking place primarily from urban to rural areas as one of the factors leading to increases in poverty. Some of the urban-rural migrants include retired workers (who were employed in urban parts of Mazabuka or elsewhere like Lusaka and the Copperbelt provinces), and persons living with AIDS who come to be nursed by their family members in the village. However, not all "immigrants" who settle in Magobbo have problems. For instance, some of the better-off or wealthy retirees from the urban areas have been bringing capital or assets into Magobbo. Some of them provide employment to the locals through offer of piecework in their crop fields as well as other work such as operating their grinding mills or small retail shops.

However, the main concern among some of the community members in Magobbo is that the better-off "immigrants" have been changing use and access rights to land by converting it from customary tenure to leasehold or titled land for their exclusive use. These "immigrants" and some of the local farmers who have been born and raised in Magobbo have mainly converted their customary land to titled land in order to benefit from the sugar out grower scheme supported by the Zambia Sugar Company. Participation in the sugar out grower scheme is restricted to farmers who own private land or have secure title deeds or leasehold tenure. With this condition, the local wealthy or better-off households have responded and acquired title deeds to their land where they have established sugar fields. These farmers have been assisted with construction of basic infrastructure such as furrows for irrigation of the sugarcane crop. These sugarcane fields owned by these households are in addition to the regular fields on other customary land where they cultivate other crops such as maize, groundnuts, millet and sorghum.

This development of shifting to private ownership of land has brought strong resentment among some of the locals since it is perceived as a threat to rural land ownership, in which the well-off have exclusive rights to private land while the poor subsist on the traditional customary land. The main concern expressed by the informants was that the "immigrants" and the farmers participating in the sugar out grower schemes have been fencing off their titled land and this has been denying other households' full access to the common property resources such as grazing land for livestock, trees and forests products as well as local streams. This has been leading to conflicts especially when some people are accused of trespassing and in instances where livestock destroy crops and, in particular, the sugar cane crop in the field.

\subsection{Idiosyncratic Shocks}

As shown in the preceding section, the respondents in the FGD identified covariate shocks that affect the entire community in Magobbo. During the discussions, the respondents also identified idiosyncratic shocks which affect individual households. It is of course realized that many of the covariate shocks or events identified in the preceding section also affect specific individual households in different ways mainly due to differences in wealth 
or poverty status. The following section highlights how the identified idiosyncratic shocks have combined to bring about downward mobility or destitution among individual households in Magobbo.

\subsubsection{Agricultural Production Shocks}

Crop failure is mainly caused by drought and floods due to erratic rainfall patterns. Uncontrolled fires and insect pests and disease may also lead to serious loss of crops in the field or in storage. Inability to carry out critical agricultural tasks such as weeding when faced with chronic illnesses or death of household members who provide labour may lead to poor crop performance. The other major causative factor for crop failure mentioned by the respondents is the inability of farmers to purchase and apply optimal fertilizer to the soils. This has led to poor crop productivity or failure, particularly of maize the staple crop which requires inorganic fertilizers to give good yields.

The respondents in the FGD also observed that apart from crop failure, the households in Magobbo have been experiencing losses of livestock due to theft and disease outbreaks. The losses of livestock, particularly cattle, have been increasing mainly due to livestock diseases occasioned by the deterioration of the public veterinary extension and other agricultural support services throughout the country. The shock of the loss of livestock like cattle that are utilized for draught power has negatively affected the crop production and food security of some households in Magobbo. In fact, some of the informants claimed that there has been a reduction in cultivated land area over the past 20 years - primarily as a result of a combination of factors such as the loss of animal draught power and lack of purchased inputs, mainly, fertilizer. This finding is consistent with other studies in Zambia and Pakistan which found that the high cost of fertilizer is one of the major production constraint seriously affecting farmers (World Bank, 2007; Amir et al. 2013).

\subsubsection{Agricultural Marketing Shocks}

The respondents in the FGD identified the problem of limited market access as one the most important shocks affecting households in Magobbo. As mentioned earlier, the liberalization policies also entail that there is no guaranteed market for farmers' produce through the publicly supported marketing boards and cooperatives. The smallholder farmers now have to bear all the transport costs and transaction costs related to selling or marketing their produce. These changes in the operation of the agricultural markets has contributed to impoverishing some households who are unable to meet their marketing costs or let alone find buyers for their produce. Due to poor infrastructure in rural areas, few traders venture into output markets. This has led to development of thin markets and consequently total market failure.

Efforts by the government to address marketing challenges by purchasing smallholder farmers' produce through the Food Reserve Agency (FRA) has not fully addressed the problem. The FRA which is mandated as a buyer of last resort is equally unable to buy most of the crops. This is especially the case with maize, the staple crop. The respondents observed that when the farmers have a good harvest, sometimes the maize is left to rot in the farms or used to feed chickens or cattle because there is no market for the same.

\subsubsection{Weather and Environmental Shocks}

In general, all the communities, which were visited and interviewed in Magobbo indicated that there have been negative changes in the environment, which have adversely affected their livelihoods. They observed that erratic weather patterns leading to droughts or floods intermittently hit households in the study area. The severity of the erratic weather patterns lies mainly in the chronic food insecurity that results thereafter. The floods and droughts wipe out staple crops like maize in the fields.

Respondents also observed that it is a challenge to manage natural resources that are accessed by all community members. They observed that there has been increased deforestation; depletion of fish stocks in local streams; and water sources have been encroached leading to increased pollution and siltation. All these problems of environmental degradation in Magobbo have mainly been attributed to increased population in the area and this has invariably negatively affected the livelihoods of the poor households who rely on harvesting natural resource products such as firewood, fish, honey and mushrooms. This finding corroborates findings in Zambia and elsewhere in Sub-Saharan Africa on the challenges posed by climate change and environmental degradation (Thurlow et al., 2009; Kessy, 2005; Eriksen \& Silva, 2009; Kangalawe et al., 2011).

\subsubsection{Shocks Associated with Morbidity and Mortality}

Major shocks that were mentioned in every village or community interviewed in Magobbo were those associated with chronic illness, disability and death. When a household is affected by HIV and AIDS or other chronic illnesses, the households experience reductions in their agricultural productivity due to fact that more time is spent on nursing the sick at the expense of work in the fields and this negatively affects the yields. Household 
resources are also spent on acquiring drugs, and meeting other medical expenses. In cases of death, the poor households have to meet funeral and other related costs such as transport and food for the mourners. Most of these households are normally unable to meet these costs and they are usually forced to draw on their savings such as livestock or grains which they liquidate to meet the funeral costs. The HIV and AIDS pandemic and other chronic illnesses have also resulted in an increase in problems associated with care for orphans. Informants in the FGD indicated that some poor households find it difficult to fully support and care for orphans left by their deceased relatives. Most of the orphaned children usually end up dropping out of schools due to lack of support. The girl children end up in forced early marriages or engage in prostitution as a way to survive.

\subsubsection{Behavioral Shocks}

Abuse of alcohol, primarily among men, was identified as one the shocks or factors responsible for movement into poverty. Drunkenness is a problem widespread in Zambia and during the FGD in Magobbo, respondents, mainly the women expressed concern about drunkenness among the men and male youth. Both men and women observed that the high drop-out rate from schools and unemployment are among the reasons why the youth and men tend to resort to alcoholism. They further observed that in some households, the men have gone overboard with alcoholism and this behavior has led them to serious social problems. For instance, the women complained that some men spend most of their earnings on alcohol, at the expense of more pressing household requirements. Sometimes men even incur debts due to alcohol abuse, resulting in impoverishment. These findings are similar to studies in Tanzania and Uganda which found serious concerns on the social and economic cost of heavy alcohol consumption among men in rural areas (Bird and Shinyekwa, 2003; Kessy, 2005).

Furthermore, respondents alleged that some men have also been abandoning their families. This phenomena of husbands deserting their wives and families is common and can be attributed to behaviour related shocks such as alcohol abuse and elopement with other women. Some men simply fail to cope with the demands and responsibilities of looking after their families and desert them. Others simply abandon their families through migration to other districts in search of employment. The abandoned wives struggle to carry out livelihood activities without spousal support exacerbating their vulnerability and poverty. These results corroborate Malesu's (2013) findings in Zambia's Kalabo and Mazabuka districts which clearly show that women left behind by their spouses due to migration in search of employment face serious economic challenges such that some of them are forced into prostitution, and hence making them highly vulnerable to HIV infections.

\subsubsection{Shocks Associated with Crime}

Respondents in the FGD indicated that crime related shocks such as theft commonly occur in Magobbo. Some of the major assets stolen include household possessions, maize grain and livestock especially cattle and goats. Respondents observed that cases of livestock theft have risen in recent years due to increased poverty. Most of these thefts are mostly committed by some delinquent youths in the community who connive with other felons from Mazabuka urban who come to buy the stolen livestock and other assets. Households that are victims of these thefts, particularly the theft of oxen, suffer losses in that they are unable to cultivate their crop fields in a timely manner. For most poor households, loss of assets such as household goods, goats or chickens to theft can be a great set-back since these prized possessions are cash reserve which are useful in periods of food shortage. This finding corroborates with study findings in Uganda and Tanzania which noted that theft is a common shock affecting the livelihoods of farmers in rural communities (The Republic of Uganda, 2002; Kessy, 2005).

\subsection{Risk Management Strategies}

Rural households in Magobbo are aware of the risks or shocks they face, and they accordingly implement a variety of risk management strategies to deal with these. This study analyzed the shocks and risk management strategies reported by informants in Magobbo using the Social Risk Management (SRM) framework. The SRM framework categorizes the risk management strategies into three groups. The strategies implemented before a shock occurs are known as Risk Reduction Strategies, and those implemented during the occurrence of the shock are known as Risk Mitigation Strategies. The Risk Coping Strategies are the ones implemented after the occurrence of a shock. Table 1 presents a summary of the major shocks and the risk management strategies utilized by the smallholders in Magobbo. 
Table 1. Risk management strategies utilized by the smallholders in Magobbo

\begin{tabular}{ll}
\hline Shock/Risk & \\
\cline { 2 - 3 } Crop failure & Risk Prevention strategies \\
& number of crops. Some of the better-off or \\
& wealthy households are producing sugarcane \\
& under the out grower scheme \\
& - Crop Substitution: Production of hybrid \\
& maize is being abandoned in favor of other \\
& crops (millet, sorghum, native maize) which \\
& require less inorganic fertilizers and are \\
& adapted to the local environment. \\
& - Adoption of Conservation Agricultural \\
& Technologies: households are practicing \\
& Conservation farming to improve soils and \\
& soil-water retention \\
& • Storing cereal crops and raising livestock: \\
& some better-off households store cereal crops \\
& mainly maize) in granaries and raise animals \\
for sale in case of crop failure. Livestock and \\
stored grain serve as a cash reserve
\end{tabular}

Loss of Livestock (due to Disease or Theft)
Risk Management Strategies

$\begin{array}{ll}\text { Risk Mitigation strategies } & \text { Risk Coping strategies } \\ \text { - Irrigation of crops } & \text { - Piecework: After a crop failure, } \\ \text { - Intensification of crop } & \text { some poor households work as } \\ \text { cultivation } & \text { labourers in the fields of other } \\ & \text { better-off households. }\end{array}$

- Selling Livestock or other assets: Some households sell livestock and assets like bicycles after loss of crops in order to obtain cash and food.

- Livelihoods Diversification: The poor make clay pots, mats or baskets for sale. However, most of them make charcoal from local trees for sale.

- Gathering wild products: Some households gather a variety of wild plant foods such as mushrooms and honey for sale and consumption

- Seeking Assistance:

Households obtain food aid from some public emergency response programs to survive after crop failures.

- Reducing Consumption: Fewer meals are consumed after loss of crops.

- Procurement of extra numbers of livestock for breeding

- Procurement of veterinary drugs and services for livestock immunization

- Procuring information on veterinary or livestock husbandry from public extension services.

- Formation of Neighborhood Watch Groups to help prevent livestock theft

- Construction of kraals or pens to house the livestock near the homesteads or compounds.

- Provision of water to livestock near the homesteads or compounds to reduce chances of theft.

- Distribution or dispersal of the animals among several relatives/friends in order to reduce or avoid transmission of diseases.
- Procuring treatment for sick animals.

- Slaughter of sick animals

- Search and arrest of livestock thieves
- Livestock re-stocking through public or NGO programs such as Heifer International, etc.

- Getting replacement livestock from other family members or friends.

- Oxen hiring from other households (to carry out tillage operations). 
Loss of labour due to illness of family member
Loss of

Breadwinner (as a result of abandonment or death)
- Embarking on preventive health care actions such as hand washing, use of proper sanitation, use of chlorine treated water, and immunizations.

- Discarding traditional practices that increase chances of sexual transmission of HIV and AIDS (such as early marriages, traditional sexual cleansing of widows and widowers, widow inheritance, etc.)

- Adjusting or changing behavior to avoid infection with HIV and AIDS (such as acceptance of use of condoms, abstinence, or monogamy)
- Getting drugs and treatment from the local public health facilities.

- Getting traditional medicines or herbs and treatment from local traditional healers.

- Other household members like children assisting or doing the work that is usually carried out by adults

- Relatives from the extended family providing assistance with the nursing care for the sick.

- Church members or NGO home-based care programs providing assistance with the nursing care for the sick.

- Carry out preventive health care actions or measures (as above)

- Fostering relationships and obligations in the extended family.
- Carrying out piecework in the fields of other households for an income

- Selling livestock to obtain cash to meet immediate needs

- Begging for food or money from family, friends and other community members.

- Being dependent on child labor

- Pulling the children out of their schools (this is usually the last recourse).

- Selling stored food (especially grains).

- Consuming smaller quantities of meals

- Inheritance of widows by brothers-in-law (levirate marriages)

- Some widows remarry other spouses within or outside the community

- Getting any form of assistance from members of the extended family

- Females (widows) and their children adjust to start doing work that was usually done by the deceased male household head.

- Selling off livestock, farm implements or other assets to obtain cash

- Forced early marriage of daughters to acquire support or to obtain lobola (bride price).

- Chopping or slashing forest trees to make charcoal for sale.

- Selling vegetables from gardens

- Getting small credit or loans from public empowerment programmes or NGOs

- Earn income from prostitution or commercial sex. 


\begin{tabular}{|c|c|c|}
\hline $\begin{array}{l}\text { other assets due to } \\
\text { theft }\end{array}$ & $\begin{array}{l}\text { prevent theft and other social vices. } \\
\text { - Securing property in households or storing } \\
\text { grains in houses. } \\
\text { - Moral persuasion of community members to } \\
\text { change behavior such as refraining from } \\
\text { excessive consumption of alcohol and theft of } \\
\text { property. }\end{array}$ & $\begin{array}{l}\text { from relatives. } \\
\text { - Begging or borrowing food } \\
\text { from friends and family }\end{array}$ \\
\hline
\end{tabular}

As can be seen in Table 1, households in Magobbo implement or practice a range of risk management strategies to address various shocks that affect them. For instance, in terms of prevention strategies in the area of crops and livestock, these include crop diversification; implementation of conservation farming practices intended to improve yields in case of drought or moisture stress; stockpiling of grains; breeding of livestock that are resistant to disease and vaccinations, and so on. Mitigation strategies are also practiced to reduce the probable impact of a shock. In agricultural practices, these include crop intensification and livelihoods diversification. In livestock production, these include strategies such as obtaining treatment for sick animals or slaughter of the sick animals. These findings on the types of risk management strategies or coping strategies that were practiced in Magobbo are consistent with study findings conducted in various places around the world such as in Uganda (Helgeson et al., 2008); Zimbabwe (Kinsey et al., 1998); Burkina Faso (Sauerborn et al., 1996); Mozambique (Eriksen and Silva, 2009); Bangladesh (Paul, 1998; Sen, 2003); Ghana (Aasoglenang \& Bonye, 2013); Ethiopia (Debebe et al., 2013); Tanzania (Kangalawe et al., 2011)

Coping strategies are the most commonly practiced since they relieve the impact of shocks or set-backs after they have occurred. The rural households in Magobbo have savings or "insurance" in order to cushion themselves from these shocks. These savings or "insurance" are in the form of livestock (cattle, goats, pigs, chickens); produce stored in granaries (maize, millet, groundnuts and beans); and crops stored in the field (cassava). They normally sell these assets or savings when they are affected by shocks like droughts, illness and so on. The money raised from the sale of these assets is used to buy other food or meet medical costs. Carter et al. (2006) called such practices 'destructive coping strategies' which actually aggravate vulnerability and perpetuate poverty. Households usually sell whatever assets they own, starting with the least valuable and then the more valuable as they try to cope with stresses like food shortages. According to the respondents in FGD, asset sales usually start with chickens, pigs or goats and then extend to young bulls or heifers, and ultimately to the sale of cows or oxen. In desperate situations, households are forced to reduce the intake of food. The sale of oxen have severe consequences to the welfare of households. Such measures reduce the capacity of households to produce, thereby increasing their vulnerability to subsequent food shortages. In the same vein, most coping strategies are not only detrimental to the affected households, but also to the community as a whole. This is the case particularly during times of drought and crop failure, when the poor households turn to common property resources to fill the gap in their livelihoods. For instance, the cutting of trees to produce charcoal has led to deforestation in Magobbo and other parts of the country.

\section{Conclusion}

This research provides evidence that rural households in Zambia face multiple covariant and idiosyncratic shocks which have been leading to downward mobility or increased poverty. The study findings show that a majority of the households in Magobbo have experienced downward economic mobility during the past ten to twenty years Only a few, particularly, the better-off and wealthy households have experience upward economic mobility. Upward mobility or improvement among the minority households is mainly attributed to earning incomes through their participation in a sugar out grower scheme. Increased poverty among the majority households is attributable to factors such as market liberalization policies; increased morbidity and mortality due to the HIV and AIDS pandemic and other chronic illnesses; adverse consequences of climate change and deterioration of the natural resources; adverse consequences of family breakdown caused by spousal abandonment, divorce and widowhood; and adverse consequences of loss of production assets to crime.

The study results also show that the households practice several risk management strategies to address shocks and set-backs that affect them. These risk management strategies include a range of prevention, mitigation and coping strategies. An understanding of these strategies is critical in designing or implementing public intervention programs that can assist in building the resilience of rural households. For instance, crop diversification and conservation farming are practiced by most rural households as risk prevention strategies to 
avoid serious crop failure in case of erratic rains or drought. Therefore, interventions such as the promotion of conservation farming through the public extension services have been greatly assisted and have been relatively successful due to the fact that some of the households have indigenous knowledge as well as vast experience of what works in their local environments to sustain livelihoods. Rural people's responses to risks, shocks and adversity are complex and varied, and public intervention programs can certainly learn from these if they have to be effective in addressing the challenges of poverty.

\section{Acknowledgements}

This research was financed by a grant provided by the Organization of Social Science Research in Eastern and Southern Africa (OSSREA).

\section{References}

Aasoglenang, A. T., \& Bonye, S. Z. (2013). Rural Livelihoods Diversity: Coping Strategies in Wa West District in Northern Ghana. European Scientific Journal, 9(35). Retrieved May 12, 2014, from http://eujournal.org/index.php/esj/article/viewFile/2189/2074

Adger, W. N., \& Vincent, K. (2005). Uncertainty in adaptive capacity. Comptes Rendus Geoscience, 337(4), 399-410. http://dx.doi.org/10.1016/j.crte.2004.11.004

Adger, W. N., Huq, S., Brown, K., Conway, D., \& Hulme, M. (2003). Adaptation to climate change in the developing world. Progress in Development Studies, 3(3), 179-195. http://dx.doi.org/10.1191/1464993403ps060oa

Amir, R. M, Shahbaz, B., Ali, T., \& Zafar, M. I. (2013). Analysis of Household Food Security Concerns and Coping Strategies of Small Farmers in Northwestern Highlands of Pakistan. Pak. J. Agri. Sci., 50(3), 505-510. Retrieved May 12, 2014, from http://www.nccr-pakistan.org/publications_pdf/General/Amir-PJAS-2013.pdf

Aryeetey, G. C., Jehu-Appiah, C., Kotoh, A., Spaan, E., Arhinful, D. K., Baltussen, R, van der Geest, S., \& Agyepong, I. A. (2013). Community concepts of poverty: an application to premium exemptions in Ghana's National Health Insurance Scheme. Globalization and Health, (9), 1-12. http://dx.doi.org/10.1186/1744-8603-9-12

Ashong, K., \& Smith, D. R. (2001). Livelihoods of the Poor in Ghana: A Contextual Review of Ghana-wide definitions and trends of poverty and the poor with those of peri-urban Kumasi. Retrieved December 9, 2013, from http://www.ucl.ac.uk/dpu-projects/drivers_urb_change/urb_society/pdf_liveli_vulnera/ DFID_Ashong_livelihoods_urban_transition_Kumasi_Ghana.pdf

Bird, K., \& Shinyekwa, I. (2003) Multiple Shocks and Downward Mobility: Learning from Life Histories of Rural Ugandans. Chronic Poverty Research Centre Working Paper No. 36. http://dx.doi.org/10.2139/ssrn.1754417

Bryceson, D. H., \& Fonseca, J. (2006). Risking Death for Survival: Peasant Responses to Hunger and HIV/AIDS in Malawi. World Development, 34(8), 1654-1666. doi:10.1016/j.worlddev.2006.01.007

Carney, D. (Ed.). (1998). Sustainable rural livelihoods: What contributions can we make? London, Department for International Development (DFID).

Carter, M. R., Little, P. D., Mogues, T., \& Negatu, W. (2006). Shocks, Sensitivity and Resilience: Tracking the Economic Impacts of Environmental Disaster on Assets in Ethiopia and Honduras. DSGD Discussion Paper No. 32. International Food Policy Research Institute (IFPRI). Washington D.C. Retrieved January 12, 2013, from http://www.ifpri.org/sites/default/files/publications/dsgdp32.pdf

Central Statistical Office (CSO), (2012a). Living conditions monitoring survey report 2006 and 2010. Central Statistical Office, Lusaka, Zambia. Retrieved December 10, 2013, from http://www.zamstats.gov.zm

Central Statistical Office (CSO). (2012b). 2010 Census of Population and Housing: Volume 11- National Descriptive Tables. Central Statistical Office, Lusaka, Zambia. Retrieved December 10, 2013, from http://www.zamstats.gov.zm

Chambers, R. (2006). Vulnerability, Coping and Policy (Editorial Introduction). IDS Bulletin, 37(4), 33-40. http://dx.doi.org/10.1111/j.1759-5436.2006.tb00284.x

Debebe, Z. Y., Mebratie, A., Sparrow, R., Abebaw, D., Dekker, M., Alemu, G., \& Bed, A. S. (2013). Coping with shocks in rural Ethiopia. ASC Working Paper 110 / 2013. African Studies Centre Leiden, The Netherlands. Retrieved

December

10 ,

2013 ,

from 
https://openaccess.leidenuniv.nl/bitstream/handle/1887/21582/ASC-075287668-3345-01.pdf?sequence=2

Dercon, S. (2004). Growth and Shocks: Evidence from Ethiopia. Journal of Development Economics, 74, 309-329. http://dx.doi.org/10.1016/j.jdeveco.2004.01.001

Dercon, S. (2005a). Vulnerability: A Micro-perspective, Paper presented at the Annual Bank Conference on Development Economics, Amsterdam. Washington DC: The World Bank.

Dercon, S. (2005b). Risk, Poverty and Vulnerability in Africa. Journal of African Economies, 14(4), 483-488. http://dx.doi.org/10.1093/jae/eji023

DFID. (2000). Sustainable Livelihoods Guidance Sheets. Department for International Development. Retrieved from http://www.eldis.org/vfile/upload/1/document/0901/section2.pdf

Ellis, F. (2000). Rural Livelihoods and Diversity in Developing Countries. Oxford: Oxford University Press.

Ellis, F., \& Mdoe, N. (2003). Livelihoods and Rural Poverty Reduction in Tanzania. World Development, 31(8), 1367-1384. http://dx.doi.org/10.1016/S0305-750X(03)00100-1

Eriksen, S., \& Silva, J. A. (2009). The Vulnerability context of a Savanna area in Mozambique: Household Drought Coping Strategies and Responses to Economic Change. Environmental Science \& Policy, 12(1), 33-52. http://dx.doi.org/10.1016/j.envsci.2008.10.007

Farrington, J. (2005). Social Protection and Livelihood Promotion in Agriculture: Towards Operational Guidelines. Paper for OECD Povnet, Renewable Natural Resources and Agriculture Team, DFID, London.

Farrington, J., Slater, R., \& Holmes, R. (2004). The Search for Synergies between Social Protection and the Productive Sectors: the Agriculture Case', Working Paper 232. London: Overseas Development Institute. Retrieved December 10, 2013, from http://www.odi.org/sites/odi.org.uk/files/odi-assets/publications-opinion-files/1876.pdf

Francis, P. A., Milimo, J. T., Njobvu, C. A., \& Tembo, S. P. M. (1997). Listening to Farmers: Participatory Assessment of Policy Reform in Zambia's Agriculture Sector. Retrieved January 15, 2014, from http://elibrary.worldbank.org/doi/book/10.1596/0-8213-4025-5

Haan, L., \& Zoomers, A. (2005). Exploring the Frontier of Livelihood Research. Development and Change, 36(1) 27-47. http://dx.doi.org/10.1111/j.0012-155x.2005.00401.x

Helgeson, J. F., Dietz, S., \& Hochrainer-Stigler, S. (2013). Vulnerability to Weather Disasters: The Choice of Coping Strategies in Rural Uganda. E\&S, 18(2). http://dx.doi.org/10.5751/ES-05390-180202

Holzmann, R., \& Jörgensen, S. (2000). Social Risk Management: A New Conceptual Framework for Social Protection and Beyond. Social Protection Discussion Paper 0006, Washington DC: World Bank. Retrieved January 15, 2014, from http://siteresources.worldbank.org/SOCIALPROTECTION/Resources/SP-Discussion-papers/Social-RiskManagement-DP/0006.pdf

Holzmann, R., Sherburne-Benz, L., \& Tesliuc, E. (2003). Social Risk Management: The World Bank's Approach to Social Protection in a Globalizing World. Social Protection Department. Washington DC: World Bank. Retrieved January 15, 2014, from http://siteresources.worldbank.org/SOCIALPROTECTION/Publications/20847129/SRMWBApproachtoSP. pdf

Kalinda, T., \& Tembo, R. (2010). Sexual Practices and Levirate Marriages in Mansa District of Zambia. Electronic Journal of Human Sexuality, 13. Retrieved January 15, 2014, from http://www.ejhs.org

Kangalawe, R, Mwakalila, S., \& Masolwa, P. (2011). Climate Change Impacts, Local Knowledge and Coping Strategies in the Great Ruaha River Catchment Area, Tanzania. Natural Resources, 2(4), 212-223. http://dx.doi.org/10.4236/nr.2011.24027

Kessy, F. (2005). Rural Income Dynamics in Kagera Region, Tanzania: A Report Prepared for the World Bank. Economic and Social Research Foundation (ESRF). Retrieved December 15, 2013, from http://www.edi-africa.com/docs/Kessy\%202004,\%20full\%20report.pdf

Kinsey, B., Burger, K., \& Gunning, J. W. (1998). Coping with drought in Zimbabwe: Survey evidence on responses of rural households to risk. World Development, 26(1), 89-110. http://dx.doi.org/10.1016/S0305-750X(97)00124-1

Malesu, P. M. (2013). Livelihood and coping strategies of men and women in the context of male labour 
migration: A gender perspective: A case of Mazabuka and Kalabo Districts. Masters Dissertation, Department of Gender Studies, University of Zambia. Retrieved June 15, 2014, from http://dspace.unza.zm:8080/jspui/handle/123456789/3285

Mortimore, M. J., \& Adams, W. M. (2001). Farmer adaptation, change and 'crisis' in the Sahel. Global Environmental Change, 11, 49-57. http://dx.doi.org/10.1016/s0959-3780(00)00044-3

Orr, A., \& Mwale, B. (2001). Adapting to Adjustment: Smallholder Livelihood Strategies in Southern Malawi. World Development, 29(8), 1325-1343. http://dx.doi.org/10.1016/S0305-750X(01)00042-0

Paul, B. K. (1998). Coping mechanisms practised by drought victims (1994/5) in North Bengal, Bangladesh. Applied Geography, 18(4), 355-373. http://dx.doi.org/10.1016/S0143-6228(98)00026-5

Sauerborn, R., Adams, A., \& Hien, M. (1996). Household Strategies to Cope with the Economic Costs of Illness. Social Science \& Medicine, 43(3), 291-301. http://dx.doi.org/10.1016/0277-9536(95)00375-4

Scoones, I. (1998). Sustainable Rural Livelihoods: A Framework for Analysis. IDS Working Paper 72. Retrieved January 15, 2014, from https://www.ids.ac.uk/files/dmfile/Wp72.pdf

Sen, B. (2003). Drivers of Escape and Descent: Changing Household Fortunes in Rural Bangladesh. World Development, 31(3), 513-534. http://dx.doi.org/10.1016/S0305-750X(02)00217-6

Shanmugaratnam, N. (2008). Between War \& Peace in Sudan \& Sri Lanka. Oxford: James Currey and African Academic Press.

The Republic of Uganda. (2002). Uganda Participatory Poverty Assessment Process: Second Participatory Poverty Assessment Report: Deepening the Understanding of Poverty. Ministry of Finance, Planning and Economic Development. Retrieved January 15, 2014, from http://www.participatorymethods.org/sites/participatorymethods.org/files/deepning\%20the\%20understandin g\%20of\%20poverty.pdf

Thurlow, J., Zhu, T., \& Diao, X. (2009). The Impact of Climate Variability and Change on Economic Growth and Poverty in Zambia. IFPRI Discussion Paper 00890. International Food Policy Research Institute (IFPRI), Washington, DC. Retrieved January 15, 2014, from http://www.ifpri.org/sites/default/files/publications/ifpridp00890.pdf

Van Campenhout, B. (2006). Locally Adapted Poverty Indicators Derived from Participatory Wealth Rankings: A Case of Four Villages in Rural Tanzania. http://dx.doi.org/10.1093/jae/ej1041

Vogel, C. (2005). "Seven Fat Years and Seven Lean Years"? Climate Change and Agriculture in Africa.' IDS Bulletin, 36(2), 30-35. http://DOI: 10.1111/j.1759-5436.2005.tb00192.x

World Bank. (2007). Zambia Poverty and Vulnerability Assessment. Report No. 32573-ZM Retrieved January 15, 2014 , from http://www-wds.worldbank.org/external/default/WDSContentServer/WDSP/IB/2007/10/04/000020439_20 071004094458/Rendered/PDF/325730ZM.pdf

Yamin, F., Rahman, A., \& Huq, S. (2005). Vulnerability, adaptation and climate disasters: a conceptual overview. IDS Bulletin, 36(4), 1-14. Retrieved January 15, 2014, from http://www.preventionweb.net/files/7789_Overview3641.pdf 


\section{Appendix A}

Map of Zambia showing location of Southern Province

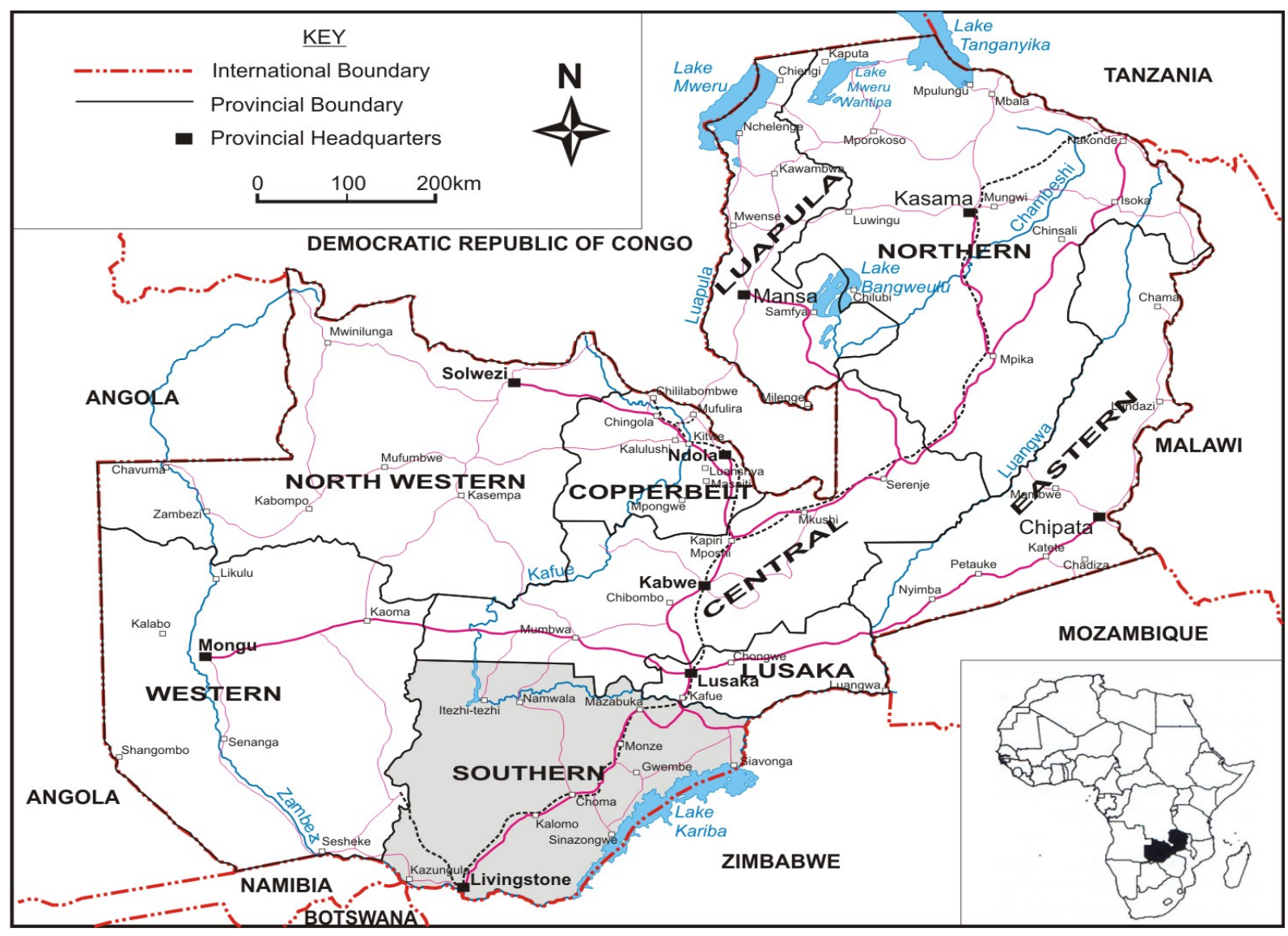

Appendix B

Maps of Southern Province \& Mazabuka District showing location of Magobbo

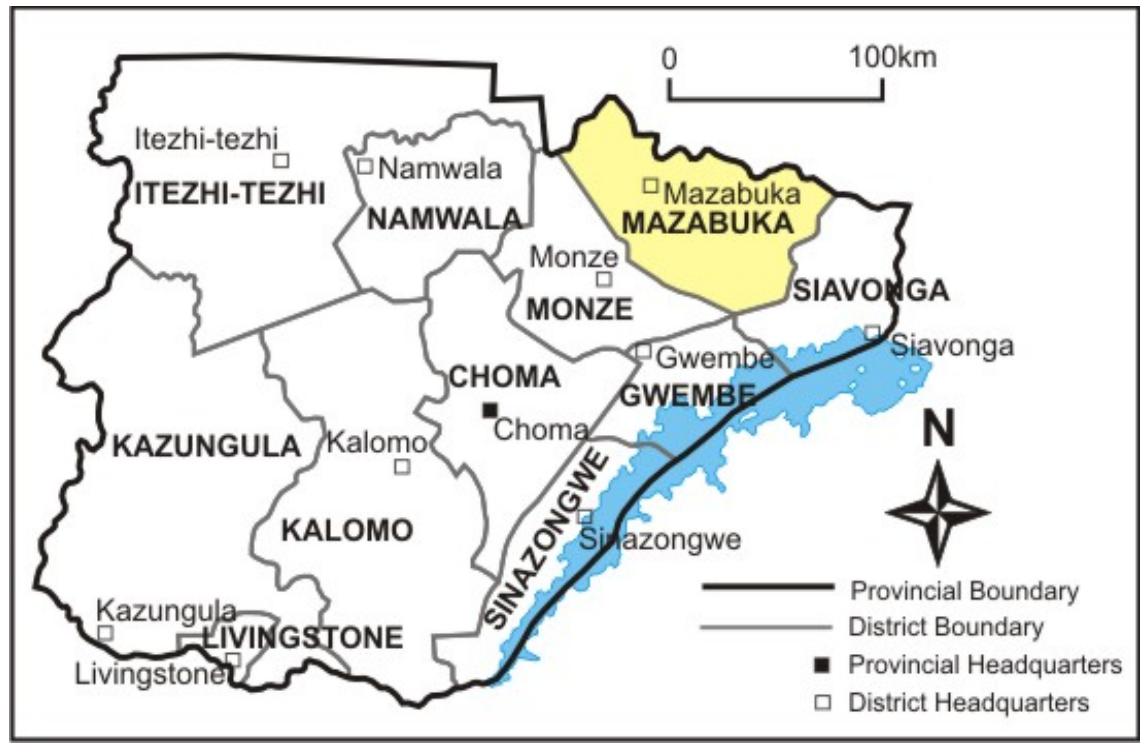




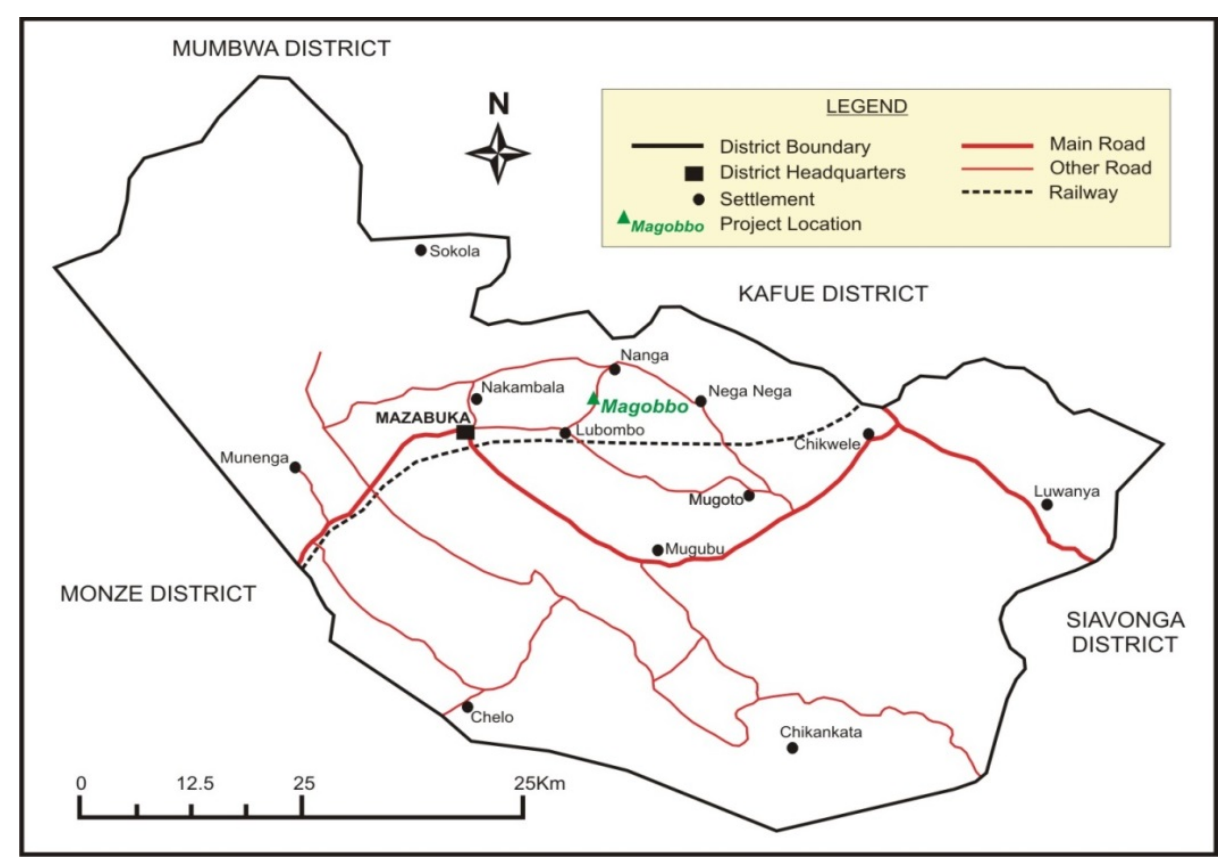

\section{Copyrights}

Copyright for this article is retained by the author(s), with first publication rights granted to the journal.

This is an open-access article distributed under the terms and conditions of the Creative Commons Attribution license (http://creativecommons.org/licenses/by/3.0/). 